\title{
Effect on Environment by Burning Different Agricultural Waste
}

\author{
Dapinder Deep Singh ${ }^{1}$, Gursimran Singh ${ }^{2}$, Prof. Siby John ${ }^{3}$ \\ ${ }^{1}$ Assistant Professor, Department of Civil Engineering, Chandigarh University, Gharuan, Mohali \\ ${ }^{2}$ ME Student, Department of Environmental Engineering, PEC University of Technology, Chandigarh. \\ ${ }^{3}$ Professor, Department of Environmental Engineering, PEC University of Technology, Chandigarh
}

\begin{abstract}
Many of the developing countries produce huge quantities of agro residues but they are used inefficiently causing extensive pollution to the environment. The major residues are rice husk, coffee husk, coir pith, jute sticks, bagasse, groundnut shells, mustard stalks and cotton stalks. The objective was to analyze the burning characteristic of paddy straw briquettes, cotton plant waste, corn sticks, saw dust briquette, wood and paddy straw, these were burnt and combustibles percentage, $\mathrm{CO}$ ( $\mathrm{ppm}$ ) and $\mathrm{NO}(\mathrm{ppm})$ were noted by multi gas analyzer. By analyzing the flue gases coming out during burning of these fuels, then plotting the graph of different parameters like combustibles, $\mathrm{CO}$ and $\mathrm{NO}$ which were obtained during burning of fuels with respect to time. Also the ash content left after burning was recorded. On combining all these parameters briquettes proves out to be clean source of energy, briquettes burn slowly giving out a constant amount of heat and less amount of combustibles as compared to other agricultural residue.
\end{abstract}

\section{Introduction}

Ericson and prior (1990) realize that deforestation and wood fuel shortages are likely to become pressing problems in many countries has turned attention to other types of biomass fuel. Agricultural residues are, in principle, one of the most important of these. They arise in large volumes and in rural areas which are often subject to some of the worst pressure of wood shortage. However, residues are often bulky and difficult to burn so various conversion techniques have been developed. One of the oldest of these is briquetting which has been used in Europe since the $19^{\text {th }}$ centuries to make fuel from low grade peat ant and brown coals.

Many of the developing countries produce huge quantities of agro residues but they are used inefficiently causing extensive pollution to the environment. The major residues are rice husk, coffee husk, coir pith, jute sticks, bagasse, groundnut shells, mustard stalks and cotton stalks. Sawdust, a milling residue is also available in huge quantity. Apart from the problems of transportation, storage, and handling, the direct burning of loose biomass in conventional grates is associated with very low thermal efficiency and widespread air pollution. The conversion efficiencies are as low as $40 \%$ with particulate emissions in the flue gases in excess of $3000 \mathrm{mg} / \mathrm{Nm}^{3}$ In addition, a large percentage of unburnt carbonaceous ash has to be disposed of. In the case of rice husk, this amounts to more than $40 \%$ of the feed burnt. As a typical example, about 800 tones of rice husk ash are generated every day in Ludhiana (Punjab) as a result of burning 2000 tones of husk. Briquetting of the husk could mitigate these pollution problems while at the same time making use of this important industrial/domestic energy resource.

Briquetting technology is yet to get a strong foothold in many developing countries because of the technical constraints involved and the lack of knowledge to adapt the technology to suit local conditions. Overcoming the many operational problems associated with this technology and ensuring the quality of the raw material used are crucial factors in determining its commercial success.

\section{Objectives of the study}

- To analyze the burning characteristic of commonly available crop residue like paddy straw, maize \& cotton sticks as well as wooden chips.

- To study the burning characteristic of paddy straw \& saw dust briquettes and compare it with the burning of common agricultural residue.

\section{Material And Methods}

To meet the set objectives for studying the burning characteristic of paddy straw briquettes a known quantity of six type of fuels: paddy straw briquettes, cotton plant waste, corn sticks, saw dust briquette, wood, paddy straw was burnt in a traditional furnace. Then with the help of multi gas analyzer readings were taken to analyze the gases coming out during burning of briquettes and agricultural residue.

Then after the complete burning the weight of ash of each fuel was taken. 
Sampling: Six fuels: paddy straw briquettes, cotton plant waste, corn sticks, saw dust briquette, wood, paddy straw were burnt to analyze the sample of gases during the burning of these fuel and readings were taken by multi gas analyzer and these readings were written in tabular form.

\section{Results And Discussion}

Table Observation recorded during burning of cotton plant waste

\begin{tabular}{|l|l|l|l|l|}
\hline Sr. no. & Time(minutes) & Combustibles $(\%)$ & CO $(\mathrm{ppm})$ & NO(ppm) \\
\hline 1 & 0 & .02 & 1.08 & 24 \\
\hline 2 & 2 & .02 & .53 & 60 \\
\hline 3 & 4 & .02 & 1.45 & 8 \\
\hline 4 & 6 & .02 & .84 & 8 \\
\hline 5 & 8 & .04 & 1.9 & 28 \\
\hline 6 & 10 & .03 & .97 & 10 \\
\hline 7 & 12 & .03 & .65 & 6 \\
\hline
\end{tabular}

Table Observation recorded during burning of corn sticks:

\begin{tabular}{|l|l|l|l|l|}
\hline Sr. no. & Time(minutes) & Combustibles $(\%)$ & CO $(\mathrm{ppm})$ & NO(ppm) \\
\hline 1 & 0 & .01 & .26 & 33 \\
\hline 2 & 3 & .01 & .27 & 46 \\
\hline 3 & 6 & .02 & .29 & 56 \\
\hline 4 & 9 & 0.8 & 1.9 & 60 \\
\hline 5 & 12 & 1.3 & 1.9 & 150 \\
\hline 6 & 15 & 0.8 & 1.3 & 90 \\
\hline
\end{tabular}

Table Observation recorded during burning of paddy straw briquette:

\begin{tabular}{|l|l|l|l|l|}
\hline Sr. no. & Time(minutes) & Combustibles $(\%)$ & $\mathrm{CO}(\mathrm{ppm})$ & NO(ppm) \\
\hline 1 & 0 & 0.1 & .17 & 14 \\
\hline 2 & 5 & 0.2 & .82 & 90 \\
\hline 3 & 10 & 0.2 & .208 & 95 \\
\hline 4 & 15 & 0.3 & .245 & 103 \\
\hline
\end{tabular}

Table Observation recorded during burning of saw dust briquette:

\begin{tabular}{|l|l|l|l|l|}
\hline Sr. no. & Time(minutes) & Combustibles $(\%)$ & CO(ppm) & NO(ppm) \\
\hline 1 & 0 & 0.1 & .028 & 23 \\
\hline 2 & 3 & 0.2 & .364 & 28 \\
\hline 3 & 6 & 1.0 & 1.850 & 88 \\
\hline 4 & 9 & 0.8 & 1.611 & 72 \\
\hline 5 & 12 & 0.2 & 0.608 & 50 \\
\hline
\end{tabular}

Table Observation recorded during burning of wood:

\begin{tabular}{|l|l|l|l|l|}
\hline Sr. no. & Time(minutes) & Combustibles $(\%)$ & $\mathrm{CO}(\mathrm{ppm})$ & $\mathrm{NO}(\mathrm{ppm})$ \\
\hline 1 & 0 & 0.01 & 0.072 & 12 \\
\hline 2 & 3 & 0.01 & 0.12 & 38 \\
\hline 3 & 6 & 0.01 & 0.13 & 42 \\
\hline 4 & 9 & 0.01 & 0.12 & 29 \\
\hline 5 & 12 & 0.02 & 0.37 & 32 \\
\hline 6 & 15 & 0.01 & 0.14 & 43 \\
\hline
\end{tabular}

The objective was to analyze the burning characteristic of paddy straw briquettes, cotton plant waste, corn sticks, saw dust briquette, wood, paddy straw were burnt and combustibles percentage, $\mathrm{CO}$ ( $\mathrm{ppm}$ ) and NO $(\mathrm{ppm})$ were noted by multi gas analyzer.

Comparison of combustibles percentage of paddy straw briquettes, cotton plant waste, corn sticks, saw dust briquette, wood, and paddy straw: 


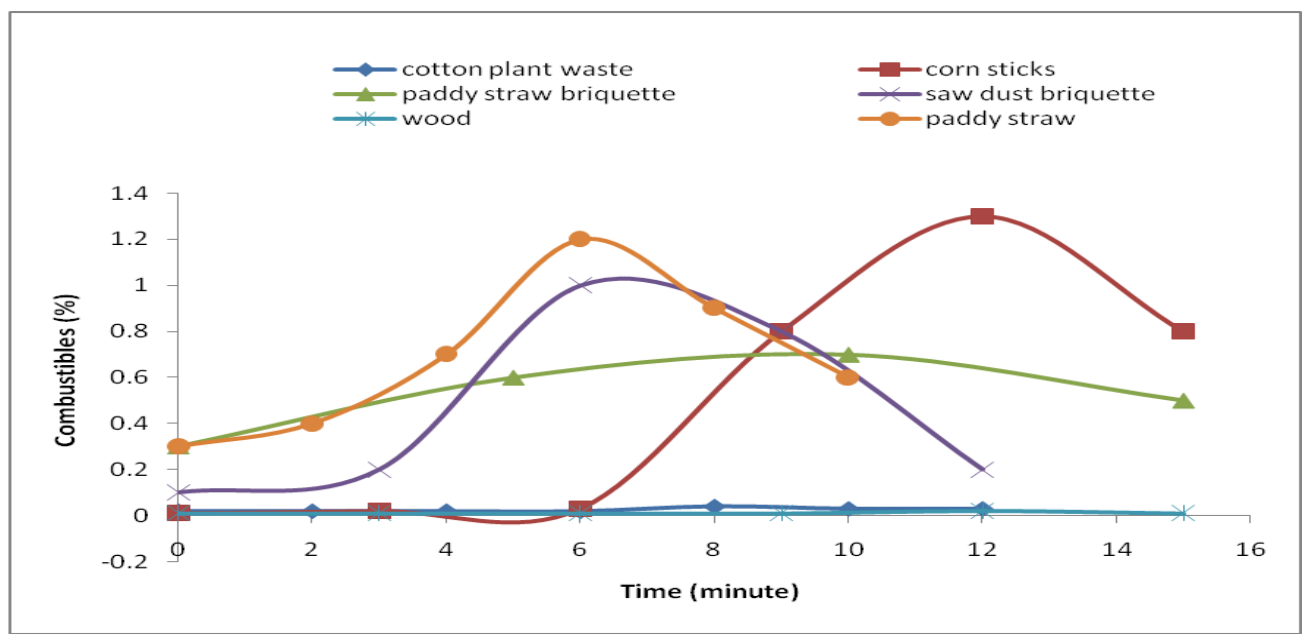

Fig. Comparison of combustible percentage v/s time

Comparison of combustibles percentage of paddy straw briquettes, cotton plant waste, corn sticks, saw dust briquette, wood, paddy straw was done by plotting graph between combustible percentage and time interval. In graph different lines show the percentage of combustibles of the fuels burnt with respect to the time. Saw dust briquette and paddy straw briquettes have combustible percentage neither high nor low, while combustible percentage of corn stick is higher, while combustible percentage of wood and cotton plant waste is low. So both briquettes burn slowly and completely.

Comparison of carbon monoxide (ppm) of paddy straw briquettes, cotton plant waste, corn sticks, saw dust briquette, wood, and paddy straw:

Comparison of carbon monoxide (ppm) of paddy straw briquettes, cotton plant waste, corn sticks, saw dust briquette, wood, and paddy straw was done by plotting graph between carbon monoxide (ppm) and time interval. In graph different lines show carbon monoxide (ppm) of the fuels burnt with respect to the time. Saw dust briquette cotton plant waste and corn stick produce large amount of CO ( $\mathrm{ppm})$, while paddy straw briquettes, paddy straw and wood produce low value of carbon monoxide. So paddy straw briquettes, paddy straw and wood are cleaner fuel.

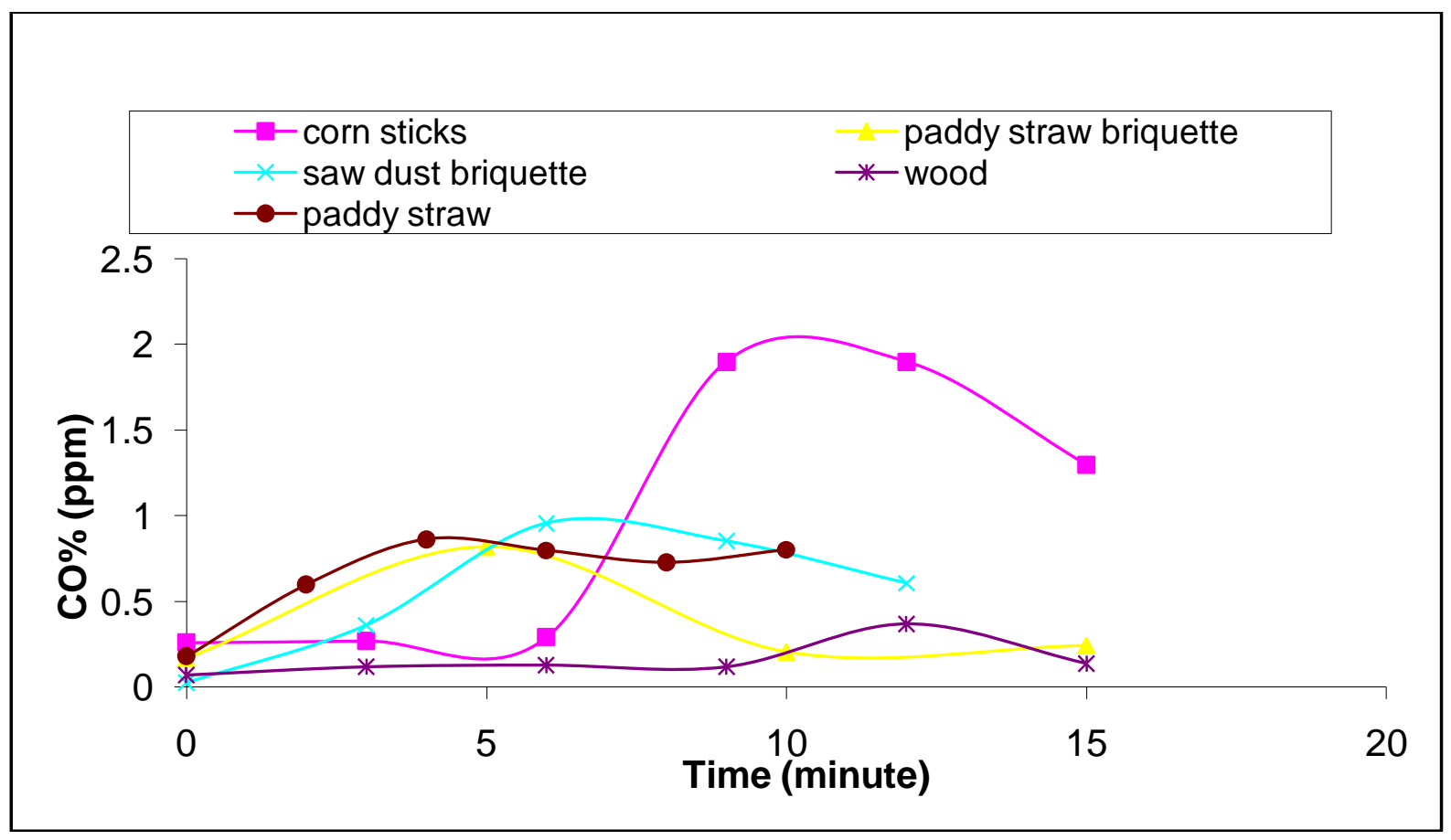

Fig. Comparison of carbon monoxide (ppm) v/s time 
Comparison of nitric oxide (ppm) of paddy straw briquettes, cotton plant waste, corn sticks, saw dust briquette, wood, and paddy straw:

Comparison of nitric oxide (ppm) of paddy straw briquettes, cotton plant waste, corn sticks, saw dust briquette, wood, and paddy straw was done by plotting graph between nitric oxide (ppm) and time interval. This graph is shown in fig. In graph different lines show nitric oxide (ppm) of the fuels burnt with respect to the time. Corn stick and paddy straw produce large amount of NO (ppm), while paddy straw briquettes, saw dust briquette, wood and cotton plant waste produce low value of nitric oxide. Saw dust briquette value of NO decreases with time while that of paddy straw briquette is high and increasing with time. So saw dust briquette is cleaner fuel.

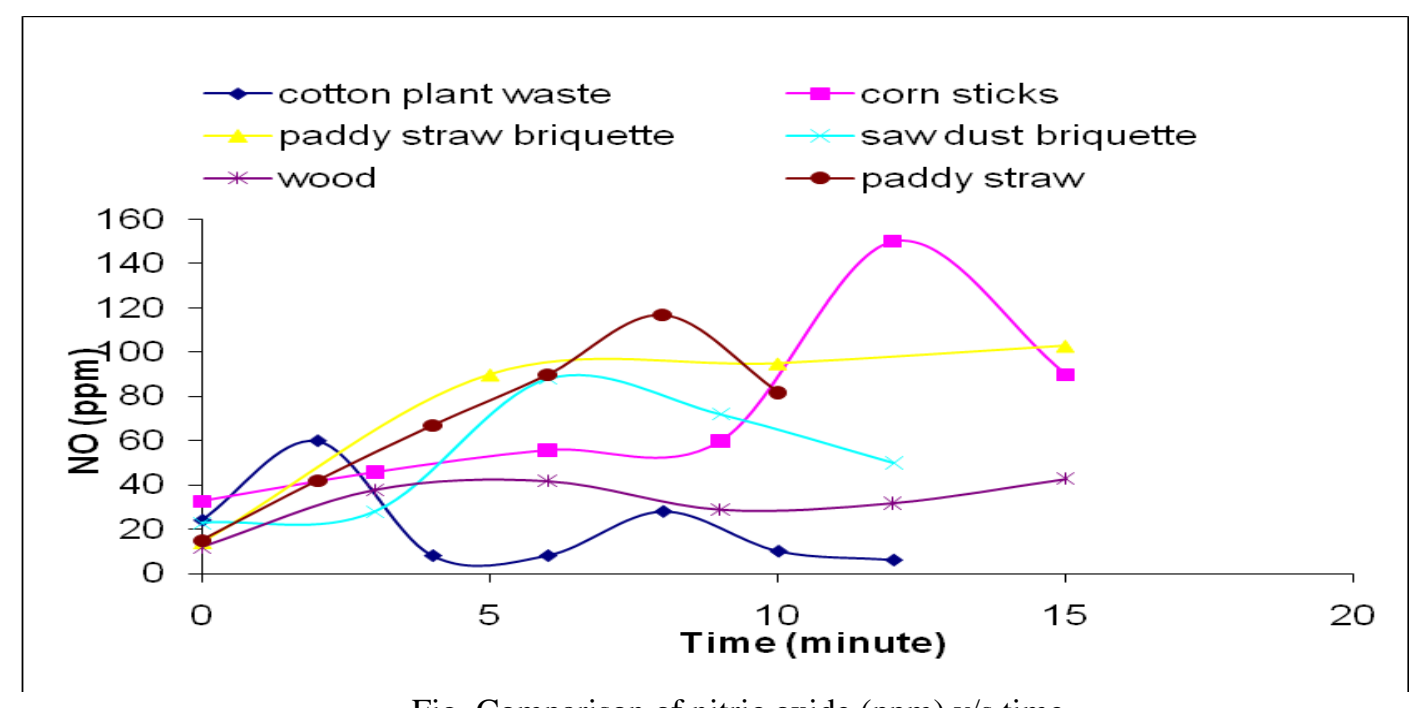

Fig. Comparison of nitric oxide (ppm) v/s time

\section{Ash content:}

For analyzing the burning characteristic of paddy straw briquettes, cotton plant waste, corn sticks, saw dust briquette, wood, and paddy straw, a known amount of these six fuels were burnt, after the complete burning of these six materials sample of their ash were taken and weighted. Ash content of these six materials have been given in table 4.1

Table Ash content of fuels burnt

\begin{tabular}{|l|l|l|l|l|}
\hline Fuel & $\begin{array}{l}\text { Initial weight of } \\
\text { fuel burnt(gm) }\end{array}$ & $\begin{array}{l}\text { Time for complete } \\
\text { burning (minutes) }\end{array}$ & Weight of ash (gm) & Percentage ash (\%) \\
\hline Cotton plant waste & 200 & 12 & 50 & 25 \\
\hline Corn sticks & 200 & 15 & 27 & 13.5 \\
\hline Paddy straw straw & 200 & 10 & 43 & 21.5 \\
\hline $\begin{array}{l}\text { Paddy } \\
\text { briquettes }\end{array}$ & 15 & 40 & 20 \\
\hline Saw dust briquettes & 200 & 12 & 14 & 7 \\
\hline wood & 200 & 16 & 13 & 6.5 \\
\hline
\end{tabular}

\section{Conclusion}

The present study was undertaken with the objective of studying the burning characteristic of paddy straw briquettes, cotton plant waste, corn sticks, saw dust briquette, wood, and paddy straw. For analyzing the gases coming out during burning of these fuels equipment called multi gas analyzer was used.

By analyzing the flue gases coming out during burning of these fuels, then plotting the graph of different parameters like combustibles, $\mathrm{CO}$ and $\mathrm{NO}$ which were obtained during burning of fuels with respect to time. Also the ash content left after burning was recorded. On combining all these parameters briquettes proves out to be clean source of energy, briquettes burn slowly giving out a constant amount of heat and less amount of combustibles as compare to other agricultural residue. Carbon monoxide and Nitric oxide release by briquette is also less as compare to other agricultural residue. So briquettes are a good alternative for other agricultural residues. 


\section{References}

[1]. Chopra A.K. (1991) Testing of LPT based briquettes machine and its briquettes B. Tech project report, department of processing and agricultural structures, Punjab Agricultural University Ludhiana.

[2]. Pathak, B.S. and Singh, A (1988). Husk utilized as fuel, Agricultural mechanism in Asia, Africa and Latin America, 19 (3) PP65-70

[3]. Rodgers, J.B. (1936). Thermal and physical properties of fuel briquettes made from agricultural waste and other waste products. Agri. Engg.17 (5):199-204.

[4]. Khurmi R. S., Gupta Joyeeta A text book of thermal engineering. Chapter 12 page 301-323 